\title{
IMPLEMENTASI MODEL PEMBELAJARAN TAI TERHADAP ORAL ACTIVITIES DAN HASIL BELAJAR KOGNITIF C1-C4 MATERI EKSKRESI
}

Sri Eka Kusumasari ${ }^{1 *}$, Much. Fuad Saifuddin ${ }^{1}$

${ }^{1}$ Universitas Ahmad Dahlan, J. Ringroad Selatan, Kragilan, Jawa Tengah

* corresponding author | email :sri1500008143@webmail.uad.ac.id

\begin{abstract}
Received 23 December 2019
Accepted 2 April 2020

Published 15 April 2020

ABSTRAK

doi http://dx.doi.org/10.17977/um052v11i2p40-48

Kegiatan pembelajaran IPA yang masih monoton membuat siswa kurang tertarik mengikuti kegiatan pembelajaran. Kurangnya aktivitas siswa dalam pembelajaran membuat nilai rata-rata ulangan harian di bawah KKM. Penelitian ini bertujuan untuk mengetahui implementasi model pembelajaran TAl terhadap oral activities dan hasil belajar kognitif C1-C4 pelajaran IPA siswa kelas VIII materi sistem ekskresi di SMP Muhammadiyah 9 Yogyakarta. Penelitian ini merupakan penelitian quasi eksperimen dengan desain penelitian posttest-only control design. Populasi dalam penelitian adalah siswa kelas VIII SMP Muhammadiyah 9 Yogyakarta T.A 2018/2019. Teknik pengumpulan data dengan cara observasi dan tes dengan instrumen penelitian lembar observasi dan soal tes. Data yang diperoleh dianalisis secara deskriptif kuantitatif. Hasil uji independent sample t-test oral activities menunjukkan signifikansi < nilai a yaitu $0,00<$ 0,05. Hasil uji mann whitney hasil belajar C1-C4 menunjukkan Asymp.Sig. (2-tailed) $<\alpha$ yaitu 0,001 <0,05. Sehingga dapat disimpulkan adanya pengaruh model TAl terhadap oral activities dan hasil belajar C1-C4.
\end{abstract}

\section{Keyword : model, TAl, oral activities}

Artikel telah diseminarkan pada acara 3rd SYMBION (Symposium on Biology Education) pada tanggal 31 Agustus 2019 | Universitas Ahmad Dahlan

Pembelajaran merupakan suatu upaya yang dilakukan guru dalam menyampaikan materi serta meningkatkan kemampuan siswa pada ranah pengetahuan, keterampilan dan sikap. Proses pembelajaran yang baik dapat dilihat dari kegiatan pembelajaran yang dilakukan dan hasil yang diperoleh dari kegiatan pembelajaran tersebut. Sehingga kegiatan pembelajaran yang efektif haruslah dapat mencapai tujuan pembelajaran yang ditentukan.

Setiap materi dalam proses pembelajaran memiliki karakteristik yang berbeda-beda, oleh karena itu kegiatan pembelajarannya juga harus berbeda. Kegiatan pembelajaran disesuaikan dengan karakteristik materi dan siswa agar proses pembelajaran berjalan dengan efektif dan efisien, dimana siswa juga terlibat di dalam kegiatan pembelajaran tersebut dan ikut berperan besar dalam pembelajaran yang dilakukan. Oleh karena itu, dalam pembelajaran guru harus mampu memilih model pembelajaran dan media yang tepat sesuai dengan karakteristik mata pelajaran dan karateristik siswa salah satunya yaitu pada mata pelajaran IPA - biologi.

Berdasarkan observasi pada beberapa kelas di SMP Muhammadiyah 9 Yogyakarta pada tanggal 
Jurnal Pendidikan Biologi | Vol. 11, No. 2, Februari 2020, pp. 40-48

Kusumasari, dkk | Implementasi Model Pembelajaran Tai ...

20 Februari 2019 terlihat dalam proses kegiatan pembelajaran IPA kelas VIII kurang kondusif. Siswa kurang memperhatikan penjelasan dari guru. Bahkan dari awal guru membuka pelajaran siswa masih belum fokus berpusat perhatiannya pada guru. Selain itu, guru yang menjelaskan hanya dengan menggunakan metode ceramah dan menulis di papan tulis membuat siswa kurang tertarik mengikuti pelajaran, hal ini terlihat dari kurangnya peran aktif siswa dalam kegiatan pembelajaran.

Selama observasi di beberapa kelas tersebut juga terlihat kemampuan oral activities siswa masih kurang. Terlihat masih rendahnya rasa ingin tahu siswa selama kegiatan pembelajaran, hal ini dibuktikan masih jarang siswa yang bertanya atau menjawab pertanyaan dari guru. Mereka hanya menjawab sesekali saat diberi pertanyaan oleh guru. Namun dalam diskusi juga mereka masih kurang dalam menyampaikan pendapatnya, terlihat dalam kerja kelompok hanya salah satu siswa saja yang mengerjakan tugas yang diberikan.

Kurangnya aktivitas siswa dalam pembelajaran menyebabkan rata-rata nilai kelas ulangan harian masih di bawah KKM yang ditentukan yaitu 68. Hanya satu kelas dari lima kelas yang rata-rata nilai ulangan di atas KKM yaitu 73,38 sedangkan kelas yang lain masih di bawah 68 . Hal tersebut menunjukkan bahwa kemampuan kognitif siswa kelas VIII pada mata pelajaran IPA masih rendah. Menurut guru IPA materi sistem ekskresi merupakan materi yang baru untuk siswa kelas VIII di kurikulum 2013, karena sebelumnya di Kurikulum Tingkat Satuan Pendidikan. Sehingga kemungkinan cukup sulit untuk menyampaikan pada siswa kelas VIII karena dilihat dari materi yang banyak terdapat istilah-istilah baru. Berdasarkan hasil nilai ulangan sistem ekskresi tahun lalu kelas IX juga menunjukkan masih rendah, dari nilai KKM yang ditentukan sekolah yaitu 70 .

Salah satu model pembelajaran yang melibatkan aktivitas siswa dan hasil belajar adalah model pembelajaran Team Assisted Individualization (TAI). Tipe model pembelajaran kooperatif ini merupakan model pembelajaran yang menggabungkan pembelajaran secara kooperatif dan pembelajaran individual (Maarip dan kasronudin, 2016:225). Menurut Shoimin (2014:202) kelebihan dari model pembelajaran Team Assisted Individualization (TAI) antara lain melibatkan siswa untuk aktif dalam proses pembelajaran, siswa diajarkan bagaimana bekerja sama dalam suatu kelompok, mereka dapat berdiskusi, berdebat atau menyampaikan gagasan, konsep, dan keahlian sampai benarbenar memahaminya.

Berdasarkan hasil penelitian oleh Meilani (2017) menunjukkan bahwa dengan menggunakan model pembelajaran Team Assisted Individualization (TAI) memberikan pengaruh yang signifikan terhadap aktivitas dan hasil belajar siswa pada materi kelarutan dan hasil kali kelarutan. Tujuan penelitian ini adalah untuk mengetahui implementasi model pembelajaran Team Assisted Individualization (TAI) terhadap oral activities dan hasil belajar ranah kognitif C1-C4 IPA siswa kelas VIII materi sistem ekskresi di SMP Muhammadiyah 9 Yogyakarta.

\section{METODE}

Penelitian ini termasuk dalam penelitian quasi eksperimen atau eksperimen semu dengan desain penelitian posttest-only control design. Penelitian ini dilaksanakan di SMP Muhammadiyah 9 Yogyakarta pada bulan April sampai dengan bulan Mei 2019. Sampel yang digunakan pada penelitian yaitu dua kelas VIII yang diambil berdasarkan teknik simple random sampling, dimana satu kelas dijadikan sebagai kelas kontrol dan satu kelas lainnya sebagai kelas eksperimen. Teknik pengumpulan data dengan menggunakan teknik observasi dan tes dengan instrumen pengumpulan data lembar observasi oral activities siswa dan soal pilihan ganda. Teknik analisis data yang digunakan yaitu deskriptif kuantitatif diolah dengan menggunakan SPSS 20 dengan uji prasyarat (normalitas dan homogenitas) dan uji hipotesis menggunakan uji independent sample t-test dan uji mann whithney.

\section{HASIL}

\section{Keterlaksanaan Pembelajaran}

Data keterlaksanaan pembelajaran diperoleh dengan dilakukan observasi ketika kegiatan pembelajaran berlangsung pada kelas eksperimen dengan lebih menekankan pada sintak model pembelajaran Team Assisted Individualization (TAI). Hasil observasi keterlaksanaan pembelajaran 
Jurnal Pendidikan Biologi | Vol. 11, No. 2, Februari 2020, pp. 40-48

tersaji pada Tabel 1.

Tabel 1. Persentase Hasil Observasi Keterlaksanaan Pembelajaran pada Kelas Eksperimen

\begin{tabular}{cccc}
\hline & Pertemuan I & Pertemuan II & Pertemuan III \\
\hline Persentase (\%) & 100 & 100 & 100 \\
\hline Kategori & Sangat baik & Sangat baik & Sangat baik \\
\hline
\end{tabular}

Berdasarkan tabel 1 maka menunjukkan pembelajaran yang telah dilakukan pada pertemuan ke 1 sampai dengan pertemuan ke 3 diperoleh persentase yang sama yaitu 100\%. Sehingga keterlaksanaan pembelajaran yang telah dilakukan termasuk dalam kategori sangat baik.

\section{Oral Activities}

Data oral activities siswa diperoleh dengan dilakukan observasi secara langsung ketika kegiatan pembelajaran berlangsung pada kelas eksperimen maupun kelas kontrol. Rata-rata persentase skor oral activities pada kelas kontrol dan kelas eksperiment tersaji pada Tabel 2.

Tabel 2. Rata-rata Persentase Skor Oral Activities Kelas Kontrol dan Kelas Eksperimen

\begin{tabular}{ccc}
\hline Kelas & Persentase $(\%)$ & Kategori \\
\hline Kontrol & 40,37 & Kurang \\
\hline Eksperimen & 53,29 & Sedang \\
\hline
\end{tabular}

Berdasarkan tabel 2 diperoleh hasil bahwa rata-rata keseluruhan persentase oral activities pada kelas eksperimen yaitu sebesar 53,29\% lebih sedangkan rata-rata keseluruhan persentase pada kelas kontrol yaitu sebesar 40,37\%. Berdasarkan kategori penskoran oral activities menurut Akdon dan Riduwan (2009:18), rata-rata persentase keseluruhan pada kelas eksperimen menunjukkan skor dalam kategori "sedang" sedangkan pada kelas kontrol termasuk pada kategori "kurang". Perolehan persentase aspek oral activities lebih detail dapat dilihat pada Gambar 1.

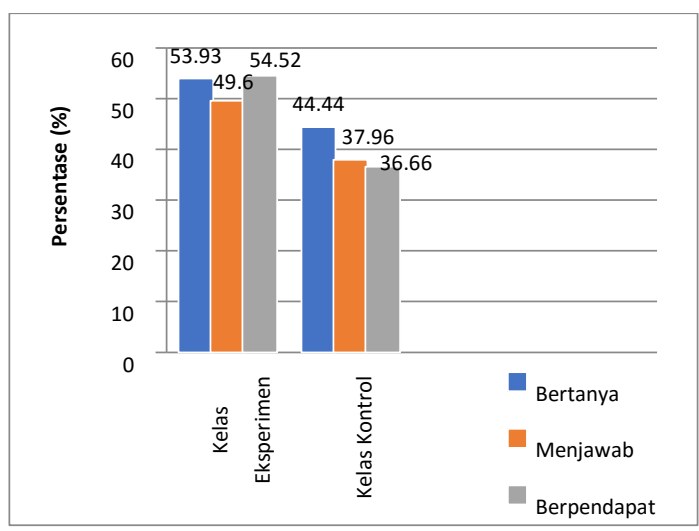

Gambar 1. Persentase Aspek Oral Activities pada Kelas Kontrol dan Kelas Eksperimen

Terlihat pada gambar 1 bahwa persentase ketiga aspek oral activities pada kelas eksperimen lebih tinggi dibandingkan kelas kontrol. Hal yang menyebabkan kategori nilai oral activities pada kelas eksperimen masih dalam kategori "sedang" diantaranya yaitu masih ada indikator oral activities yang kurang aktif dilakukan diantaranya aktivitas menjawab. Hal ini ditunjukkan dengan hasil persentase aspek oral activities menjawab pada kelas eksperimen paling rendah diantara aspek lainnya yaitu sebesar $49,60 \%$.

\section{Uji Prasyarat Oral Activities}

Hasil uji normalitas pada data oral activities disajikan pada Tabel 3. 
Jurnal Pendidikan Biologi | Vol. 11, No. 2, Februari 2020, pp. 40-48

Tabel 3. Hasil Uji Normalitas Data Oral Activities

\begin{tabular}{llccc}
\hline Kelas & & \multicolumn{3}{c}{ Kolmogorov-Smirnov } \\
\cline { 3 - 5 } & & Statistic & Df & Sig. \\
\hline Oral activities & Oral activities kelas kontrol &, 135 & 30 &, 173 \\
\hline & Oral activities kelas eksperimen &, 139 & 28 &, 175 \\
\hline
\end{tabular}

Berdasarkan hasil analisis uji normalitas dengan kolmogorov-smirnov diperoleh hasil signifikan kelas eksperimen signifikansi 0,175 >0,05 dan kelas kontrol signifikansi 0,173 $>0,05$ Sehingga dapat diambil keputusan data penelitian yang dilakukan berdistribusi normal. Hasil uji homogenitas pada data oral activities disajikan pada Tabel 4.

Tabel 4. Hasil Uji Homogenitas Data Oral Activities

\begin{tabular}{cccc}
\hline Levene Statistic & df1 & df2 & Sig. \\
\hline, 921 & 1 & 56 &, 341 \\
\hline
\end{tabular}

Berdasarkan hasil uji homogentitas dengan menggunakan levene test menunjukkan signifikansi 0,341 >0,05 maka data oral activities kelas kontrol dan kelas eksperimen dapat dikatakan homogen.

\section{Uji Hipotesis Oral Activities}

Hasil uji hipotesis pada oral activities disajikan pada Tabel 5.

Tabel 5. Hasil Uji Independent Sample T-Test

\begin{tabular}{cccccc}
\hline & Mean & $\mathrm{T}_{\text {hitung }}$ & $\mathrm{T}_{\text {tabel }}$ & $\mathrm{Df}$ & Keterangan \\
\hline Oral activities kelas kontrol & 25,43 & 3,917 & 2,003 & 56 & Ada perbedaan \\
\hline Oral activities kelas eksperimen & 33,00 & & & & Ada perbedaan \\
\hline
\end{tabular}

Berdasarkan hasil uji hipotesis menggunakan uji independent sample t-test diperoleh nilai thitung $>t_{\text {tabel }}$ yaitu 3,917 > 2,003 maka maka $\mathrm{H}_{0}$ ditolak dan $\mathrm{H}_{\mathrm{a}}$ diterima, artinya ada perbedaan rata-rata antara oral activities kelas kontrol dan kelas eksperimen. Selain itu, berdasarkan hasil analisis statistic diperoleh mean kelas eksperimen yaitu 33,54 lebih besar dibandingkan mean kelas kontrol yaitu 25,43 dengan selisih 8,14.

\section{Hasil Belajar}

Data hasil belajar diperoleh dengan memberikan soal posttest di akhir pertemuan pada kelas kontrol maupun kelas eksperimen. Setelah dilakukan posttest diperoleh hasil analisis pada Tabel 6.

Tabel 6. Persentase dan Rata-rata Nilai Posttest Kelas Kontrol dan Kelas Eksperimen

\begin{tabular}{ccccc}
\hline & \multicolumn{2}{c}{ Kelas Kontrol } & \multicolumn{2}{c}{ Kelas Eksperimen } \\
\cline { 2 - 4 } & $>$ KKM & $<$ KKM & $>$ KKM & $<$ KKM \\
\hline Persentase (\%) & 34,48 & 65,52 & 71,43 & 28,57 \\
\hline Jumlah siswa & 29 & \multicolumn{2}{c}{28} \\
\hline Rata-rata nilai & 64,60 & \multicolumn{2}{c}{73,57} \\
\hline
\end{tabular}

Berdasarkan tabel 6 maka menunjukkan bahwa persentase siswa yang hasil belajarnya diatas KKM pada kelas eksperimen lebih tinggi dibandingkan kelas kontrol. Selain itu, rata-rata nilai posttest kelas eksperimen yaitu 73,57 lebih tinggi dibandingkan rata-rata nilai posttest kelas kontrol sebesar 64,60 dengan selisih 8,37. 
Jurnal Pendidikan Biologi | Vol. 11, No. 2, Februari 2020, pp. 40-48

Kusumasari, dkk | Implementasi Model Pembelajaran Tai ...

\section{Uji Prasyarat Hasil Belajar}

Tabel 7. Hasil Uji Normalitas Kolmogorov-Smirnov Data Posttest Kelas Kontrol dan Kelas Eksperimen

\begin{tabular}{ccccc}
\hline & Kelas & \multicolumn{3}{c}{ Kolmogorov-Smirnov $^{\text {a }}$} \\
\cline { 3 - 5 } & & Statistic & df & Sig. \\
\hline Hasil belajar IPA & Kelas kontrol (konvensional) &, 207 & 29 &, 003 \\
\cline { 2 - 5 } & Kelas eksperimen (TAI) &, 204 & 28 &, 004 \\
\hline
\end{tabular}

Uji normalitas yang digunakan untuk mengetahui data hasil belajar adalah uji kolmogorovsmirnov. Berdasarkan hasil analisis diperoleh hasil posttest kelas kontrol signifikansi 00,003 dan kelas eksperimen dengan nilai signifikansi 0,004, sehingga signifikansi kelas kontrol dan kelas eksperimen < 0,05 maka data penelitian dikatakan tidak normal, maka uji hipotesis menggunakan uji nonparametrik yaitu uji mann whitney.

Tabel 8. Hasil Uji Homogenitas Data Posttest Kelas Kontrol dan Kelas Eksperimen

\begin{tabular}{cccc} 
Levene Statistic & df1 & df2 & Sig. \\
\hline, 492 & 1 & 55 &, 486 \\
\hline
\end{tabular}

Berdasarkan hasil uji homogenitas posttest kelas kontrol dan kelas eksperimen dengan levene test diperoleh nilai signifikansi 0,492 >0,05 maka data penelitian dikatakan homogen.

Uji Hipotesis Hasil Belajar

Tabel 9. Hasil Uji Mann Whitney Data Posttest Kelas Kontrol dan Kelas Eksperimen

Hasil belajar IPA

\begin{tabular}{lr}
\hline Mann-Whitney U & 202,000 \\
\hline Wilcoxon W & 637,000 \\
\hline Z & $-3,328$ \\
\hline Asymp. Sig. (2-tailed) &, 001 \\
\hline
\end{tabular}

Berdasarkan hasil uji hipotesis hasil belajar dengan menggunakan uji mann whitney diperoleh hasil asymp. Sig. (2-tailed) 0,001 $<0,05$. Berdasarkan pengambilan keputusan mann whithney $\mathrm{H}_{\mathrm{a}}$ diterima jika nilai asymp. Sig. (2-tailed) $<0,05$. Berdasarkan pengambilan data tersebut maka diambil keputusan $\mathrm{H}_{\mathrm{a}}$ diterima yang artinya rata-rata posttest antara kelas eksperimen dan kelas kontrol tidak sama.

\section{PEMBAHASAN}

\section{Keterlaksanaan Pembelajaran}

Data keterlaksanaan pembelajaran diperoleh dengan dilakukan observasi ketika kegiatan pembelajaran berlangsung pada kelas eksperimen dengan lebih menekankan pada sintak model pembelajaran Team Assisted Individualization (TAI). Berdasarkan tabel 1 maka menunjukkan pembelajaran yang telah dilakukan pada pertemuan ke 1 sampai dengan pertemuan ke 3 diperoleh persentase yang sama yaitu $100 \%$. Sehingga keterlaksanaan pembelajaran yang telah dilakukan termasuk dalam kategori sangat baik. Hal ini dikarenakan sintak model pembelajaran telah dilaksanakan oleh guru. Namun dalam pelaksanaannya ada beberapa sintak yang sedikit kurang terespon oleh siswa, misalnya yaitu pada saat kegiatan team study method terlihat bahwa sebagian siswa tidak mengoreksi hasil pekerjaan teman kelompoknya, namun mereka langsung berdiskusi secara kelompok. Hal ini menyebabkan kurangnya aktivitas bertanya pada siswa. Selain itu, pada sintak team score and team recognition tidak banyak siswa yang mengajukan pertanyaan ketika ada kelompok lain yang melakukan presentasi. Hal ini yang menyebabkan kurangnya aktivitas bertanya dan menjawab pada siswa.

Keterlaksanaan pembelajaran dengan model pembelajarn Team Assisted Individualization (TAI) 
Jurnal Pendidikan Biologi | Vol. 11, No. 2, Februari 2020, pp. 40-48

Kusumasari, dkk | Implementasi Model Pembelajaran Tai ...

ini terlaksana dengan baik karena didukung dengan adanya peran aktif siswa dalam kegiatan pembelajaran. Hal ini dapat dilihat dari adanya aktivitas oral activities yang mucul ketika kegiatan pembelajaran berlangsung. Selain itu, kegiatan pembelajaran yang menerapkan model pembelajaran Team Assisted Individualization (TAI) juga membuat siswa tertarik untuk mengikuti pembelajaran, sehingga memberi pengaruh terhadap aktivitas siswa khususnya pada oral activities siswa. Hal ini dibuktikan dengan hasil oral activities yang berbeda antara kelas kontrol dan kelas eksperimen, dimana hasil persentase oral activities kelas eksperimen lebih tinggi dibandingkan kelas kontrol yang hanya menggunakan metode ceramah.

Salah satu sintak yang membuat siswa tertarik mengikuti kegiatan pembelajaran ini adalah adanya team score and recognition, dimana diakhir presentasi akan diumumkan 3 kelompok terbaik dan diberikan penghargaan berupa sertifikat menarik. Selain itu, adanya sintak teaching groups dan team study method ini memberikan kesempatan pada siswa untuk melakukan aktivitas seperti bertanya pada teman sekelompoknya sebelum bertanya pada guru, selain itu pada sintak tersebut memungkinkan siswa untuk berpendapat. Hal tersebut sejalan dengan Sardiman (2014:100) yang menyatakan dalam belajar perlu aktivitas, sebab aktivitas langsung dalam pembelajaran siswa akan lebih mudah menguasai materi.

Proses pembelajaran dengan penerapan model pembelajaran Team Assisted Individualization (TAI) yang memungkinkan siswa aktif dalam kegiatan pembelajaran sehingga dapat meningkatkan hasil belajar siswa dibandingkan dengan kegiatan pembelajaran pada kelas kontrol. Hal ini sejalan dengan penelitian Kurniati (2015) yang menyatakan bahwa model pembelajaran Team Assisted Individualization (TAI) berpengaruh terhadap keaktifan belajar dan hasil belajar siswa. Hal ini di buktikan dengan adanya perbedaan hasil rata-rata persentase oral activities antara kelas kontrol dan kelas eksperimen dengan selisih $12,92 \%$. Sedangkan pada hasil belajar pada kelas eksperimen nilai persentase rata-ratanya lebih tinggi dari pada kelas kontrol dengan selisish $8,73 \%$.

\section{Oral Activities}

Data oral activities siswa diperoleh dengan dilakukan observasi secara langsung ketika kegiatan pembelajaran berlangsung pada kelas eksperimen maupun kelas kontrol. Berdasarkan tabel 2 diperoleh hasil bahwa rata-rata keseluruhan persentase oral activities pada kelas eksperimen yaitu sebesar 53,29\% lebih sedangkan rata-rata keseluruhan persentase pada kelas kontrol yaitu sebesar 40,37\%. Berdasarkan kategori penskoran oral activities menurut Akdon dan Riduwan (2009:18), ratarata persentase keseluruhan pada kelas eksperimen menunjukkan skor dalam kategori "sedang" sedangkan pada kelas kontrol termasuk pada kategori "kurang". Hal tersebut dikarenakan pada kelas eksperimen serangkaian kegiatan pembelajaran dengan model pembelajaran Team Assisted Individualization (TAI) memungkinkan siswa meningkatkan aktivitas lisannya.

Berdasarkan gambar 1 persentase ketiga aspek oral activities pada kelas eksperimen lebih tinggi dibandingkan kelas kontrol. Hal yang menyebabkan kategori nilai oral activities pada kelas eksperimen masih dalam kategori "sedang" diantaranya yaitu masih ada indikator oral activities yang kurang aktif dilakukan diantaranya aktivitas menjawab. Hal ini ditunjukkan dengan hasil persentase aspek oral activities menjawab pada kelas eksperimen paling rendah diantara aspek lainnya yaitu sebesar $49,60 \%$.

Rendahnya aspek bertanya pada kelas eksperimen kemungkinan disebabkan kurangnya aktivitas siswa ketika kegiatan team score and recognition, dimana saat kelompok lain melakukan presentasi sedikit siswa yang mengajukan pertanyaan sehingga aktivitas menjawab siswa juga menjadi rendah. Berdasarkan hasil analisis tersebut maka menunjukkan hasil oral activities siswa dengan model Team Assisted Individualization (TAI) lebih tinggi dibandingkan kelas yang tidak menggunkan model Team Assisted Individualization (TAI).

Berdasarkan hasil uji prasyarat uji normalitas dengan kolmogorov-smirnov pada oral activities diperoleh hasil signifikan kelas eksperimen 0,175 >0,05 dan kelas kontrol signifikansi 0,173>0,05 dapat diambil keputusan data penelitian yang dilakukan berdistribusi normal. Sedangkan hasil uji homogentitas dengan menggunakan levene test menunjukkan signifikansi 0,341>0,05 data dikatakan homogen jika nilai signifikan $>0,05$. Berdasarkan hal tersebut maka data oral activities kelas kontrol 
Jurnal Pendidikan Biologi | Vol. 11, No. 2, Februari 2020, pp. 40-48

Kusumasari, dkk | Implementasi Model Pembelajaran Tai ...

dan kelas eksperimen dapat dikatakan homogen.

Berdasarkan hasil uji hipotesis menggunakan uji independent sample $t$-test diperoleh nilai $t_{\text {hitung }}$ $>t_{\text {tabel }}$ yaitu 3,917 $>$ 2,003 maka maka $\mathrm{H}_{0}$ ditolak dan $\mathrm{H}_{\mathrm{a}}$ diterima, artinya ada perbedaan rata-rata antara oral activities kelas kontrol dan kelas eksperimen. Selain itu, berdasarkan hasil analisis statistic diperoleh mean kelas eksperimen yaitu 33,54 lebih besar dibandingkan mean kelas kontrol yaitu 25,43 dengan selisih 8,14. Sehingga terbukti bahwa model pembelajaran Team Assisted Individualization (TAI) berpengaruh terhadap oral activities siswa. Hal ini sejalan dengan hasil penelitian Meilani (2017) yang menyatakan bahwa model pembelajaran kooperatif tipe Team Assisted Individualization (TAI) memberikan pengaruh terhadap aktivitas siswa pada materi kelarutan dan hasil kali kelarutan hal ini ditunjukkan dengan hasil uji mann whitney signifikansi $0,00<0,05$.

Model pembelajaran Team Assisted Individualization (TAI) ini memberi pengaruh terhadap oral activities karena dalam penerapannya model ini memungkinkan siswa untuk aktif dalam kegiatan pembelajaran diantaranya yaitu aktivitas lisan seperti bertanya, menjawab dan mengemukakan pendapat. Aktivitas lisan tersebut dapat dilakukan dalam kegiatan teaching groups dimana memungkinkan siswa bertanya kepada guru mengenai bagian materi yang belum dipahami. Team study method memungkinkan siswa untuk bertanya pada teman dalam kelompoknya serta mengemukakan ide dalam berdiskusi. Kemudian dalam kegiatan team score and team recognition memungkinkan siswa dalam menyampaikan hasil diskusi kelompok serta menjawab pertanyaan yang diajukan oleh kelompok lain.

Selain itu, pada model Team Assisted Individualization (TAI) ini memungkinkan siswa untuk aktif dan menjalin kerjasama yang baik dengan kelompoknya, karena diakhir presentasi dipilih tiga kelompok terbaik yang diberikan reward berupa sertifikat menarik oleh guru sebagai bentuk penghargaan. Tidak hanya itu, siswa dengan model pembelajaran ini juga dapat mengembangkan kemampuan lisan mereka seperti bertanya, menjawab dan berpendapat. Hal ini sejalan dengan teori Shoimin (2014:202) yang menyatakan bahwa kelebihan dari model Team Assisted Individualization (TAI) diantaranya yaitu siswa diajarkan bagaimana bekerjasama dalam kelompok, melibatkan siswa aktif dalam kegiatan belajar, siswa dapat berdiskusi, berdebat atau menyampaikan gagasan, konsep dan keahlian sampai benar-benar memahaminya. Selain itu berdasarkan hasil penelitian Riyani (2016) keunggulan penggunaan model Team Assisted Individualization (TAI) pada pembelajaran IPA salah satunya yaitu siswa berdiskusi bertukar pikiran sehingga dapat melatih keterampilan berpikir kritis. Berdasarkan penelitian pengaruh model Team Assisted Individualization (TAI) terhadap berpikir kritis siswa sebesar $70,90 \%$.

Adanya aktivitas oral activities siswa seperti bertanya, menjawab dan mengemukakan pendapat menandakan bahwa siswa melakukan proses berpikir. Menurut Khodijah (2014:117) berpikir merupakan proses penting yang terjadi di dalam belajar, karena tanpa berpikir atau memikirkan apa yang dipelajari seseorang tidak akan memperoleh pemahaman dan pengetahuan tentang yang dipelajari tersebut. Tingginya hasil oral activities siswa pada kelas eksperimen maka siswa pada kelas eksperimen harusnya memiliki tingkat kepercayaan diri dan rasa ingin tahu yang lebih tinggi dibandingkan kelas kontrol. Karena ketika siswa bertanya maka siswa tersebut memiliki rasa ingin tahu yang tinggi dan untuk bertanya dibutuhkan rasa percaya diri untuk melakukannya. Begitu pula ketika siswa menjawab dan berpendapat, mereka perlu rasa percaya diri yang tinggi untuk dapat melakukannya. Menurut penelitian Riyani (2016) implementasi model pembelajaran Team Assisted Individualization (TAl) siswa saling tutor sebaya, berdiskusi, bertukar pikiran sehingga dapat melatih siswa dalam mengungkapkan ide-ide.

\section{Hasil Belajar}

Data hasil belajar diperoleh dengan memberikan soal posttest diakhir pertemuan pada kelas kontrol maupun kelas eksperimen. Berdasarkan tabel 6 maka menunjukkan bahwa persentase siswa yang hasil belajarnya diatas KKM pada kelas eksperimen lebih tinggi dibandingkan kelas kontrol. Selain itu, rata-rata nilai posttest kelas eksperimen yaitu 73,57 lebih tinggi dibandingkan rata-rata nilai posttest kelas kontrol sebesar 64,60 dengan selisih 8,37. Hal ini sejalan dengan hasil penelitian Halih (2016) yang menyatakan bahwa terdapat pengaruh hasil belajar matematika dengan model 
Jurnal Pendidikan Biologi | Vol. 11, No. 2, Februari 2020, pp. 40-48

Kusumasari, dkk | Implementasi Model Pembelajaran Tai ...

pembelajaran Team Assisted Individualization (TAI) hal ini ditunjukkan dengan rata-rata kelas eksperimen lebih besar dibandingkan dengan rata-rata kelas kontrol. Selain itu dari analisis ketuntasan siswa, kelas eksperimen lebih banyak yang nilainya di atas KKM.

Berdasarkan hasil uji prasyarat data hasil belajar dengan uji kolmogorov-smirnov pada tabel 7 diperoleh hasil posttest kelas kontrol signifikansi 00,003 dan kelas eksperimen dengan nilai signifikansi 0,004 , sehingga signifikansi kelas kontrol dan kelas eksperimen $<0,05$. Berdasarkan pengambilan keputusan Wijiyanto (2009:46) data dikatakan berdistribusi normal jika nilai signifikansi $>0,05$. Berdasarkan pengambilan keputusan tersebut maka data penelitian dikatakan tidak normal, maka uji hipotesis menggunakan uji nonparametrik yaitu uji mann whitney. Sedangkan berdasarkan hasil uji homogenitas posttest kelas kontrol dan kelas eksperimen dengan levene test diperoleh nilai signifikansi 0,492 >0,05. Berdasarkan hal tersebut maka data penelitian dikatakan homogen.

Berdasarkan hasil uji hipotesis hasil belajar dengan menggunakan uji mann whitney diperoleh hasil asymp. Sig. (2-tailed) 0,001 $<0,05$. Berdasarkan pengambilan keputusan mann whithney $\mathrm{H}_{\mathrm{a}}$ diterima jika nilai asymp. Sig. (2-tailed) $<0,05$. Berdasarkan pengambilan data tersebut maka diambil keputusan $\mathrm{H}_{\mathrm{a}}$ diterima yang artinya rata-rata posttest antara kelas eksperimen dan kelas kontrol tidak sama. Adanya perbedaan rata-rata antara posttest kelas kontrol dan kelas eksperimen maka dapat dikatakan ada pengaruh implementasi model pembelajarn Team Assisted Individualization (TAI) terhadap hasil belajar IPA kelas VIII materi sistem ekskresi. Hal ini sejalan dengan penelitian Lumowa dan Kusumawati (2013) yang menyatakan bahwa ada pengaruh model pembelajaran kooperatif tipe Team Assisted Individualization (TAI) terhadap hasil belajar IPA-Biologi konsep hama dan penyakit pada tumbuhan siswa kelas VIII SMPN 6 Samarinda. Hal ini dibuktikan dengan hasil $F_{\text {hitung }}>F_{\text {tabel }}$ yaitu $48,245>2,70$.

Berdasarkan hasil penelitian yang telah dilakukan dapat dikatakan pengaruh implementasi model pembelajaran Team Assisted Individualization (TAI) terhadap hasil belajar ranah kognitif C1-C4 disebabkan keterlaksanaan pembelajaran yang dilaksanakan sesuai dengan sintak model pembelajaran. Hal ini dikarenakan dalam implementasi model pembelajaran Team Assisted Individualization (TAI) melibatkan banyak aktivitas siswa salah satunya yaitu oral activities. Dibuktikan dengan perbedaan hasil rata-rata aktivitas oral activities siswa kelas eksperimen 53,29\% lebih tinggi dibandingkan kelas kontrol yaitu sebesar $40,37 \%$. Adanya perbedaan oral activities pada kedua kelas tersebut maka memberikan pengaruh terhadap hasil belajar C1-C4 siswa, hal ini dibuktikan dengan perolehan hasil rata-rata posttest kelas eksperimen 73,57 lebih tinggi dibandingkan hasil posttest kelas kontrol yaitu 64,60. Berdasarkan hasil analisis butir soal C1-C4 pada kelas eksperimen diperoleh hasil persentase $\mathrm{C} 1$ sebesar $79,75 \%$, C2 sebesar $77,67 \%$, C3 sebesar $70,23 \%$ dan $C 4$ sebesar $68,60 \%$.

Menurut Hamalik (2012:175) aktivitas siswa pada saat pembelajaran besar nilainya terhadap pengajaran karena siswa mencari pengalaman sendiri dan langsung mengalami sendiri, berbuat sendiri akan mengembangkan seluruh aspek pribadi secara integral, memupuk kerja sama yang harmonis dikalangan siswa, bekerja menurut minat dan kemampuan sendiri, memupuk disiplin kelas secara wajar dan suasana belajar menjadi demokratis, mempererat hubungan atar teman, pengajaran dilaksanakan secara realistis dan konkret sehingga mengembangkan pemahaman dan berpikir kritis dan pengajaran disekolah menjadi lebih hidup.

Berdasarkan hasil analisis yang telah dilakukan maka dapat disimpulkan bahwa implementasi model pembelajaran Team Assisted Individualization (TAI) berpengaruh terhadap oral activities dan hasil belajar C1-C4 siswa. Hal ini sejalan dengan penelitian Meilani (2013) yang menyatakan bahwa model pembelajaran Team Assisted Individualization (TAI) berpengaruh terhadap aktivitas dan hasil belajar siswa pada materi kelarutan dan hasil kali kelarutan siswa kelas XI MIPA. Berdasarkan penelitian tersebut dilaporkan hasil rata-rata nilai posttest kelas eksperimen 85,80 . Sehingga hasil penelitian ini lebih rendah dibandingkan penelitian Meilani (2013), hal ini dikarenakan adanya beberapa perbedaan diantaranya yaitu materi dan sampel yang digunakan dimana padapenelitian Meilani (2013) sampel yang digunakan yaitu siswa kelas XI yang tingkatannya lebih tinggi dibandingkan siswa SMP kelas VIII. 
Jurnal Pendidikan Biologi | Vol. 11, No. 2, Februari 2020, pp. 40-48

Kusumasari, dkk | Implementasi Model Pembelajaran Tai ...

\section{KESIMPULAN DAN SARAN}

\section{Kesimpulan}

Berdasarkan hasil penelitian yang telah dilakukan maka dapat diambil kesimpulan sebagai berikut: 1) Implementasi model pembelajaran Team Assisted Individualization (TAI) berpengaruh terhadap oral activities pelajaran IPA siswa kelas VIII materi sistem ekskresi di SMP Muhammadiyah 9 Yogyakarta. 2) Implementasi model pembelajaran Team Assisted Individualization (TAI) berpengaruh terhadap hasil belajar ranah kognitif C1-C4 pelajaran IPA siswa kelas VIII materi sistem ekskresi di SMP Muhammadiyah 9 Yogyakarta.

\section{Saran}

Model pembelajaran untuk mengaktifkan peserta didik sangat bervariasi, oleh karena itu guru disarankan untuk menggunakan berbagai variasi model pembelajaran agar kegiatan pembelajaran lebih menarik dan kondusif salah satunya yaitu model TAI. Bagi peneliti selanjutnya, perlu dilakukan variasi dari variabel penelitian untuk mengetahui lebih dalam lagi pengaruh model TAl selain terhadap oral activities dan hasil belajar ranah kognitig C1-C4, misalnya pengaruh terhadap motivasi dan interaksi siswa.

\section{DAFTAR RUJUKAN}

Akdon, Riduwan. 2013. Metode dan Teknik Menyusun Tesis. Bandung : Alfabeta.

Halih, Moh. 2016. Pengaruh Model Pembelajaran TAI (Team Asissted Individualization) terhadap Hasil

Belajar Siswa. Jurnal Buana Matematika. 6 (2): 31-36.

Hamalik, Oemar. 2012. Proses Belajar Mengajar. Jakarta: Bumi Aksara.

Khodijah, Nyanyu. 2014. Psikologi Pendidikan. Jakarta: PT Raja Grafindo Persada.

Kurniati, Ririn. 2015. Penerapan Model Pembelajaran Tipe TAI (Team Assisted Individualization) dalam Meningkatkan Keaktifan Belajar dan Pemahaman Konsep pada Mata Pelajaran Matematika Siswa Kelas XI di SMK Negeri 1 Jayapura. Jurnal Pendidikan Indonesia. 3 (3): 1-11.

Lumowa, S.V.T dan Kusumawati, Y.D. 2013. Pengaruh Model Pembelajaran Team Assisted Individualization (TAI) dan Teams Game Tournament (TGT) terhadap Hasil belajar pada Konsep Hama dan Penyakit Tumbuhan. Jurnal EduBio tropika. 1 (1): 1-60.

Maarip Aep S \& Kasronudin. 2016. Konsep dan Aplikasi Belajar \& Pembelajaran. Yogyakarta: PT leutika Nouvalitera.

Meilani, Neni, Hadiarti dan Fadhilah. 2017. Efektivitas Model Pembelajaran Kooperatif Tipe Team Assisted Individualization (TAI) pada Materi Kelarutan dan Hasil Kali Kelarutan terhadap Aktivitas Dan Hasil Belajar Siswa Kelas XI MIPA SMA Negeri 7 Pontianak. Ar-Razi jurnal IImiah. 5 (2): 215224.

Riyani, Ana, Widiyatmoko dan Wusqo. 2016. Pengaruh Model Pembelajaran Kooperatif Tipe Team Assisted Individualization Berbantuan Peta Konsep terhadap Hasil Belajar dan Keterampilan Berpikir kritis Siswa SMP Tema Kalor. Unnes Science Education Journal. 5 (2): 1280-1287.

Sardiman. 2014. Intraksi dan Motovasi belajar Mengajar. Jakarta: Rajawali Pers.

Shoimin, Aris. 2014. 68 Model Pembelajaran Inovatif dalam Kurikulum 2013. Yogyakarta: Ar-ruzz Media. 